\title{
Cheese in nutrition and health
}

\author{
Barbara WALTHER*, Alexandra SCHMID, Robert SIEBER, Karin WEHRMÜLlER
}

Agroscope Liebefeld-Posieux Research Station ALP, 3003 Berne, Switzerland

\begin{abstract}
Cheese has a long history in the human diet. In ancient times, cheese was primarily a concentrated form of milk with the benefit of a prolonged shelf life. The high content of fat and protein in cheese made it an energy-rich and nutritious food that was suitable for our hardworking ancestors. Recent advances in nutrition science have highlighted the contribution of cheese to nutrition and health. Cheese is a rich source of essential nutrients; in particular, proteins, bioactive peptides, amino acids, fat, fatty acids, vitamins and minerals. Ripened cheese is free of lactose and therefore suitable for the nutrition of lactose-intolerant individuals. There is evidence to suggest that two bioactive tripeptides, VPP and IPP, found in sour milk fermented with Lactobacillus helveticus, lower blood pressure. These peptides were also detected in specific cheese varieties in significant quantities. The high concentration of essential amino acids in cheese contributes to growth and development of the human body. Despite the presence of a notable amount of saturated and trans fatty acids, there is no clear evidence relating the consumption of cheese to any disease. Conjugated linoleic acid and sphingolipids present in cheese may have anti-carcinogenic properties. The high concentration of calcium in cheese is well known to contribute to the formation and maintenance of strong bones and teeth, but also shows a positive effect on blood pressure and helps in losing weight in combination with low-energy diets. Cheese is an important dairy product and an integral part of a healthful diet due to its substantial contribution to human health. In recent times, diet has been linked to various diseases such as diabetes, obesity, cardiovascular disease, osteoporosis and cancer, and the focus of nutrition research has shifted towards specific food ingredients contributing to nutrition and health.
\end{abstract}

\section{cheese / composition / nutrition / health}

\begin{abstract}
摘要 - 干酪的营养和健康作用。在人类的饮食中干酪有着悠久的历史。远古时代, 人类为 了延长奶的保质期, 将奶浓缩制成干酪。高含量的脂肪和蛋白质为我们勤劳的祖先提供了 充足的能量和营养。营养学研究表明干酪是一种营养和健康食品。干酪富含人体必需的 营养素,特别是蛋白质、生物活性肽、氨基酸、脂肪、脂肪酸、维生素和矿物质。成熟的 干酪不含乳糖, 因此特别适合乳糖不耐症人群。有资料显示, 在以瑞士乳杆菌 (Lactobacillus helveticus) 发酵的酸乳中存在 2 种具有降血压功能的生物活性三肽 VPP 和 IPP, 在某些特殊 的干酪中也发现这两种活性肽的含量较高。干酪中高含量的必需氨基酸有助于人体的生 长。尽管干酪中含有大量的饱和脂肪酸及反式脂肪酸, 但是没有充分的证据证明干酪的消费 与任何疾病有关。相反, 干酪中的共轭亚油酸和鞘脂类具有抗癌的特性。众所周知, 干酪中 高浓度的钙离子有利于形成和维持强壮的骨骼和锋利的牙齿, 而且还有助于保持正常的血 压, 与低能量食品结合可以起到瘦身的作用。由于干酪对人类的健康具有重要的作用, 因此 干酪是重要的乳制品, 也是健康食品的重要配料。近年来, 许多疾病的形成都与饮食直接相 关, 如糖㽷病、肥胖、心血管疾病、骨质疏松症和癌症等, 因此对营养的研究则更多是关注 特定食物成分的营养和对健康的作用。
\end{abstract}

\section{干酪 / 成分 / 营养 / 健康}

\footnotetext{
* Corresponding author (通讯作者): barbara.walther@alp.admin.ch
} 
Résumé - Fromage en nutrition et santé. Le fromage a une longue tradition dans l'alimentation humaine. Autrefois, il s'agissait principalement d'une forme concentrée de lait qui avait l'avantage d'avoir une durée de conservation prolongée. Le taux élevé de lipides et de protéines dans le fromage en fait un aliment nutritif, riche en énergie, qui convenait bien à nos ancêtres travaillant durement. Des recherches récentes en nutrition ont mis en évidence la contribution du fromage dans l'alimentation et la santé. Le fromage est une source riche en nutriments essentiels, en particulier en protéines, en peptides bioactifs, en acides aminés, en lipides, en acides gras, en vitamines et en minéraux. Le fromage affiné ne contient plus de lactose et convient donc aux personnes intolérantes à ce composant. Par ailleurs, il y a tout lieu de penser que deux tripeptides bioactifs, les VPP et IPP, détectés dans le lait fermenté par Lactobacillus helveticus, abaissent la pression sanguine. Ces peptides ont aussi été détectés en quantités significatives dans divers types de fromage. La concentration élevée d'acides aminés essentiels dans le fromage contribue à la croissance et au développement du corps humain. Malgré la présence d'une quantité notable d'acides gras saturés et trans, il n'y a aucun élément de preuve mettant en relation la consommation de fromage et une quelconque maladie. Au contraire, il semble que les acides linoléiques conjugués et les sphingolipides présents dans le fromage possèdent des propriétés anti-cancérigènes. La concentration élevée de calcium dans le fromage est connue pour contribuer à la formation et au maintien d'une ossature et d'une dentition solides, mais exerce aussi un effet positif sur la pression sanguine et aide à perdre du poids en combinaison avec un régime hypocalorique. Le fromage est un produit laitier important et fait partie d'une alimentation équilibrée en raison de sa contribution substantielle à la santé humaine. Récemment, l'alimentation a été mise en relation avec diverses maladies comme le diabète, l'obésité, les maladies cardiovasculaires, l'ostéoporose et le cancer. En conséquence, l'accent a été mis, dans les recherches sur la nutrition, sur des ingrédients alimentaires spécifiques, contribuant à une alimentation saine et donc à la santé.

\section{fromage / composition / alimentation / santé}

Abbreviations: $\mathbf{A C E}=$ angiotensin-converting enzyme, $\mathbf{C L A}=$ conjugated linoleic acid, IPP = isoleucyl-prolyl-proline, MUFA = monounsaturated fatty acid, PUFA = polyunsaturated fatty acid, $\mathbf{S F A}=$ saturated fatty acid, TFA = trans fatty acid, $\mathbf{V P P}=$ valyl-prolyl-proline.

\section{INTRODUCTION}

Cheese is one of the most ancient forms of manufactured food. It is thought that cheese-making could go as far back as 10000 BC when sheep and goats were first domesticated in the Middle East and early herdsmen would have consumed milk. Due to contaminating bacteria, milk has a short shelf life, especially in warm climates. Therefore, it might have happened that sour milk naturally separated into curds and whey, the solid curd providing an edible and nourishing food [22]. It is likely that nomadic tribes, spread from the Middle East to Western Europe and South and Central Asia, found animal-skin bags a useful way to carry milk on animals' backs when on the move. Fermentation of the milk sugars would cause the milk to curdle and the swaying motion would break up the curd and provide solid curd and drinkable whey. The curds would be removed, drained and lightly salted to provide a tasty and nourishing high protein food. The Romans then elevated this crude cheese-making to an early semblance of technology and spread it to various European regions. The basic reason for purposely processing milk into cheese is to preserve a perishable food and to convert it into a stable and storable product. It also expands the variety of food [105].

Cheese produced in Europe, where climates are cooler than in the Middle East, required less salting for preservation. With less salt and lower acidity, cheese was a suitable environment for a variety of beneficial microbes and molds, which give aged cheeses their pronounced and interesting flavors.

Nowadays, cheese consumption is widely spread throughout the world. However, the amount of cheese eaten is 
Table I. Per capita cheese consumption in various countries, 2001 to 2006 [37, 38].

\begin{tabular}{|c|c|c|c|c|c|c|}
\hline & 2001 & 2002 & 2003 & 2004 & 2005 & 2006 \\
\hline & \multicolumn{6}{|c|}{ kg per capita } \\
\hline Greece & 26.6 & 27.5 & 28.7 & 28.7 & 28.9 & 28.9 \\
\hline France & 25.8 & 25.0 & 24.8 & 24.5 & 24.5 & 23.9 \\
\hline Iceland & 22.8 & 22.3 & 23.9 & 24.7 & 23.6 & - \\
\hline Germany & 21.6 & 21.7 & 21.7 & 21.9 & 22.1 & 22.4 \\
\hline Italy & 21.4 & 21.2 & 22.3 & 23.0 & - & 23.7 \\
\hline Austria & 18.7 & 18.9 & 19.4 & 19.4 & 19.6 & 18.8 \\
\hline Switzerland & 18.2 & 18.3 & 20.2 & 21.7 & 22.2 & 22.2 \\
\hline EU 25 & 17.5 & 17.6 & 17.8 & 18.0 & 18.3 & 18.4 \\
\hline Sweden & 17.3 & 17.6 & 17.6 & 17.9 & 17.9 & 18.5 \\
\hline Finland & 16.6 & 16.5 & 16.6 & 18.3 & 18.5 & 19.1 \\
\hline Norway & 15.3 & 15.3 & 15.1 & 15.3 & 15.9 & 16.0 \\
\hline USA & 15.1 & 15.3 & 15.3 & 15.7 & 15.7 & 16.0 \\
\hline Netherlands & 14.7 & 14.7 & 14.7 & 14.7 & 14.7 & 20.4 \\
\hline Canada & 14.1 & 13.9 & 14.0 & 14.3 & 14.4 & - \\
\hline Australia & 11.6 & 12.3 & 12.4 & 11.7 & 11.9 & - \\
\hline Argentina & 11.5 & 9.6 & 8.3 & 8.9 & 10.7 & - \\
\hline Poland & 10.9 & 10.1 & 10.3 & 10.4 & 10.4 & - \\
\hline Ireland & 10.3 & 10.3 & 10.5 & 10.5 & 10.5 & 10.5 \\
\hline Czech Republic & 10.2 & 14.4 & 14.7 & 15.7 & - & - \\
\hline Portugal & 10.0 & 10.1 & 10.2 & 10.3 & - & - \\
\hline UK & 10.0 & 10.8 & 10.8 & 10.9 & 11.1 & - \\
\hline Hungary & 8.7 & 8.9 & 8.8 & 9.0 & 10.0 & - \\
\hline Spain & 8.7 & 9.1 & 9.5 & 9.5 & 9.6 & - \\
\hline New Zealand & 7.3 & 7.1 & 7.1 & 7.1 & 7.1 & - \\
\hline Slovakia & 6.3 & 9.1 & 9.3 & 8.2 & 9.3 & - \\
\hline Russia & 5.3 & 5.5 & 5.6 & 5.7 & 6.2 & - \\
\hline Japan & 1.9 & 1.8 & 1.9 & 2.0 & - & - \\
\hline Mexico & 1.9 & 2.0 & 1.9 & 2.1 & 2.1 & 2.1 \\
\hline South Africa & 1.0 & 1.0 & 0.8 & 0.6 & - & - \\
\hline Korea (Republic) & - & - & 1.2 & 1.3 & 1.4 & - \\
\hline
\end{tabular}

-: No values available.

very different from country to country. In Greece, France, Germany, Italy and Switzerland per capita consumption is more than $20 \mathrm{~kg}$ per year. At the other end of the scale, cheese consumption in
Mexico, Japan, Ukraine, South Africa and China is very low. Nevertheless, cheese consumption has risen continuously in recent years in most of the selected countries and also worldwide (Tab. I). 
Table II. Average composition of fresh, soft, semi-hard, hard and extra-hard cheese [86].

\begin{tabular}{lccccc}
\hline & Water & Protein & Fat & Lactose & $\begin{array}{c}\text { Minerals } \\
+ \text { Vitamins }\end{array}$ \\
\cline { 2 - 6 } & & & ${\mathrm{g} \cdot \mathrm{kg}^{-1}}$ & & \\
\hline Fresh cheese & 700 & 110 & 80 & 30 & 80 \\
Soft cheese & 520 & 200 & 220 & 0 & 60 \\
Semi-hard cheese & 400 & 250 & 270 & 0 & 80 \\
Hard cheese & 350 & 270 & 310 & 0 & 70 \\
Extra-hard cheese & 300 & 290 & 330 & 0 & 80 \\
\hline
\end{tabular}

Today the main reason for the consumption of cheese is not the prevention of hunger but the supply of important and essential nutrients, its manifold uses in the kitchen, and its enjoyment. Technological progress has led to a multitude of different types of cheese on the market, varying in texture and flavor. Nowadays, a shift is observable from the optimum in product quality to the optimum for the consumer. So research is no longer based on the production of high quality cheese but more and more on the commercialization of cheese as a functional food. Technology is needed for gentle processing to retain or even accumulate desired nutrients and to remove undesired compounds. Since more and more individuals would like to control their health via custom-made food, the worldwide market for Functional Food is one of the fastest-growing markets in the world.

\section{COMPOSITION OF CHEESE}

The various cheese types can be classified according to the milk used (cow, sheep, goat, buffalo), their manufacture (rennet, sour milk cheese, ultrafiltration), consistency (extra-hard, hard, semi-hard, semi-soft, soft, fresh cheese), fat content (double cream, cream, full fat, threequarters fat, half fat, quarter fat cheese), fermentation type (lactic acid, lactic and propionic acid, butyric acid), surface (hard, soft, with smear, moulds) and interior (eyes, moulds). Additionally, they differ in flavor as well as some bioactive components, which are mainly created during the different stages of ripening when the main ingredients lactose, protein and fat are broken down by fermentation, proteolysis and lipolysis [58]. Thus, the varieties of cheese on the market are enormous, which is also reflected in the variability in the composition of the different types of cheese (Tab. II). In most of the countries with a high consumption of milk products the major part is produced from cow's milk. So we have concentrated on the composition of cow's milk. They mainly consist of fat, protein and water as well as vitamins, minerals and trace elements. Lactose is rarely present [87].

\section{CHEESE AND NUTRITION}

\subsection{Lactose}

At the beginning of the cheese ripening process, lactose is partly washed out with the whey: the rest is fermented into lactic acid and further into diacetyl, acetylaldehyde, acetic acid, ethanol and $\mathrm{CO}_{2}$ [47]. The fact that ripened cheese is free of lactose $[86,88,96]$ is an advantage for most of the adult population. Approximately $70 \%$ of the global population cannot tolerate lactose in adulthood; consumption 
of milk is followed by various unpleasant symptoms such as abdominal pain, diarrhea, nausea, flatulence, etc. [34]. Nevertheless, it is not necessary for these people to avoid dairy products. All types of cheese except fresh and, in a few cases, soft cheese, are free of lactose. Therefore, lactose-intolerant people can consume these cheeses, which contribute to a healthy diet with their indispensable ingredients such as calcium [89].

\subsection{Protein}

As already mentioned, cheese is an important source of proteins and amino acids. It is well documented that cheese provides all essential amino acids except methionine and cysteine in more than the recommended quantities for children or adults [101]. Not only the proteins and amino acids play an important role in human nutrition; during the last 30 years an intermediate product of proteolysis of proteins into amino acids has moved to the center of interest - bioactive peptides. These are special amino acid sequences within the proteins. As long as they are bound in the proteins they are biologically inactive. A wide range of biological activities have been described, including opioid, blood pressure-lowering, mineralbinding, antimicrobial, immunomodulating, cell-modulating, anti-carcinogenic, anti-cariogenic, anti-thrombotic, antiinflammatory and cholesterol-lowering activities [4].

\subsection{Fat}

Another main component of cheese is fat. It varies between 20 and $35 \%$ of the dry mass. One portion $(50 \mathrm{~g})$ of full-fat cheese provides about two-thirds of the recommended daily intake of fat. Milk fat, and therefore also cheese fat (except in mold cheese, fat does not change during ripening), has an average content of $600 \mathrm{~g} \cdot \mathrm{kg}^{-1}$ fat of saturated fatty acids (SFA), $235 \mathrm{~g} \cdot \mathrm{kg}^{-1}$ fat of monounsaturated fatty acids (MUFA) and $46 \mathrm{~g} \cdot \mathrm{kg}^{-1}$ fat of polyunsaturated fatty acids (PUFA). The composition varies seasonally, and in summer saturated fatty acids are reduced in favor of the unsaturated fatty acids [86]. The most common saturated fatty acid is palmitic acid (16:0) with $260 \mathrm{~g} \cdot \mathrm{kg}^{-1}$ fat, in second place myristic acid (14:0) with $98 \mathrm{~g} \cdot \mathrm{kg}^{-1}$ fat and in third place stearic acid (18:0) with $80 \mathrm{~g} \cdot \mathrm{kg}^{-1}$ fat. All other saturated fatty acids are present at between approximately 0.2 and $31 \mathrm{~g} \cdot \mathrm{kg}^{-1}$ fat. The most common unsaturated fatty acid in milk fat is oleic acid (18:1 c9) with $165 \mathrm{~g} \cdot \mathrm{kg}^{-1}$ fat. Milk fat also provides trans fatty acids. The seasonal variation is very large; in summer $73.5 \mathrm{~g} \cdot \mathrm{kg}^{-1}$ fat, and in winter $38.3 \mathrm{~g} \cdot \mathrm{kg}^{-1}$ fat.

Trans fatty acids, especially those of industrial origin, have been accused of enhancing the risk of coronary heart disease $[110,111]$. Studies that investigated a possible similar effect of ruminant trans fatty acids did not support this hypothesis: in contrast, a neutral and even slightly negative correlation was observed both in men and women $[13,39]$. A special trans fatty acid in milk fat is conjugated linoleic acid (CLA), which is typical of ruminant fat. In cheese, the content varies between 0.1 and $2.5 \mathrm{~g} \cdot \mathrm{kg}^{-1}$ fat. Comparison of milk from the lowlands with milk from the highlands showed a threefold increase in concentration of CLA in the fat from the highlands [16]. These differences could be explained by breed and fodder. Several animal studies report various beneficial effects of CLA but only a few could also be demonstrated in humans [68] (see below).

Saturated fatty acids have a poor image because there is some evidence of a negative influence on blood lipids and therefore a possible promotion of coronary heart disease. However, in fact, individual saturated 
fatty acids influence blood cholesterol level differently [30, 74, 81, 99]. In addition, some play an important role in cell regulation by protein modification (acetylation), in gene expression as well as in the modulation of genetic regulation, in the regulation of the bioavailability of PUFA, and in fat deposition [23, 72-74].

The knowledge of these physiological functions of SFA together with the results from new epidemiological studies indicate that we have to differentiate between individual saturated fatty acids and no longer treat them as a whole. If a reduction of the total SFA intake is sought it should not be done by reducing the consumption of dairy products (in Switzerland they represent $43 \%$ of total SFA intake) since they provide a series of nutritionally interesting fatty acids, as described above [20].

\subsection{Vitamins and minerals}

Milk and dairy products contain all vitamins and minerals in different quantities [86]. One of the most important minerals in dairy products and especially in cheese is calcium. Semi-hard and hard cheese contain about 6 to $11 \mathrm{~g} \cdot \mathrm{kg}^{-1}$ cheese. The content in soft cheese is lower due to the acidification of the vat milk. One portion $(50 \mathrm{~g})$ of semi-hard or hard cheese supplies one-third to a half of the recommended daily intake of $1200 \mathrm{mg}$ calcium. In Switzerland $71 \%$ of the daily calcium intake is consumed in the form of milk and dairy products and about $20 \%$ as semi-hard and hard cheese [20]. Besides calcium, cheese is also a good source of phosphorus and zinc, and magnesium is also worth mentioning. The relatively high content of salt has often been discussed in relation to hypertension. But other ingredients in cheese such as calcium and certain bioactive peptides have been shown to neutralize a possible negative effect (see below).

One portion of hard cheese contains $15 \%$ of the daily recommended intake of vitamin $\mathrm{A}$, over $10 \%$ of $\mathrm{B}_{2}$, over $20 \%$ of $\mathrm{B}_{6}$ and almost $40 \%$ of the recommended value of $\mathrm{B}_{12}$ with an energy content of only $10 \%$ of the daily diet [98].

\section{CHEESE AND HEALTH ASPECTS}

Cheese is a rich source of bioavailable calcium. The following discussion of the health aspect of cheese mainly focuses on the role played by this specific mineral, but at the same time, specific roles played by other ingredients such as protein, bioactive peptides, CLA and sphingolipids cannot be ignored.

\subsection{Protective effect for dental caries}

Dental caries has been shown to be due to the breakdown of tooth enamel by acids which are formed during the fermentation of sugars and starches by plaque bacteria. Despite an improvement in its incidence due to a better prophylaxis, caries is still the most prevalent dental disease. To avoid corrosion of tooth enamel good hygiene, on the one hand, and an adapted nutrition, on the other hand, are helpful. Even though milk contains sugar (lactose), animal and human studies showed that it is not cariogenic [18]. Milk even reduces caries in rats when added to their normal diet [71]. According to different studies the anti-cariogenic effect of cheese products is based on various components. On the one hand, calcium and phosphorus seem to minimize the drop in plaque $\mathrm{pH}$, which means that acid production after dairy consumption is reduced [40]. Chewing a piece of cheese after a sugary food brings plaque $\mathrm{pH}$ rapidly back to neutrality [77]. Jensen et al. [42] realized that not all types of cheese are equally potent in inhibiting the drop in plaque $\mathrm{pH}$. Aged cheese seems to protect better than young and fresh cheese. 
One explanation for the protection could be a buffering effect by the stimulation of saliva flow by cheese. Saliva contains calcium and phosphate ions at super saturation which leads to a mineralization of the enamel in a neutral environment [3]. Moynihan et al. [60] measured the calcium concentration of the plaque after a meal containing cheese and a meal without cheese. The meal with cheese increased the calcium concentration of the plaque significantly more than the control meal. Jensen et al. [41] observed a remineralization of enamel when cheese or milk was used as a snack between meals. A similar result was found when the influence of milk and dairy product consumption and the progression of dental caries were studied [24]. Cheese was found to decrease the dental caries coefficient. Rat studies also showed an inhibitory effect of cheese on the metabolism or survival of cariogenic bacteria such as Streptococcus mutans [19]. Casein also plays an important role. Micellar casein selectively modifies the microbial composition of dental plaque [28]. Casein phosphopeptides react with high concentrations of calcium and phosphate to form calcium phosphate complexes. These complexes lead to remineralization of the enamel and today are incorporated in toothpaste, gels and chewing gum [9].

\subsection{Weight reduction or anti-obese effects}

Obesity is an established health hazard, increasing the risk of coronary heart disease, hypertension, diabetes and some cancers, as well as other metabolic abnormalities $[64,69,76]$. The cost in Switzerland, due to obesity, adiposity and associated subsequent diseases, was calculated at CHF 2691 million in 2001 [82].

The main causes of this epidemic disease, i.e. poor nutrition, minimal physical activity, social and cultural or other lifestyle factors as well as genetic predisposition are discussed. The recommended nutritional interventions for weight reduction vary among low-fat, low-carbohydrate and other models. When the low-fat approach is argued, milk, dairy products and especially (full-fat) cheese are usually condemned because of their high fat content. Therefore, dairy products are often omitted by people trying to lose weight.

Overweight women seem to benefit most from the intake of cheese: regular intake $\left(\geq 1\right.$ serving $\left.\cdot \mathrm{d}^{-1}\right)$ of whole milk, sour milk or cheese was inversely associ-ated with weight gain. No association was seen between a regular intake of less than 1 serving. $\mathrm{d}^{-1}$ or an increase or decrease in the intake of dairy products. When adjusted for BMI, the findings remained significant for cheese and for whole milk and sour milk for normal-weight women only. Thus, Rosell et al. [75] concluded that the association between the intake of dairy products and weight change differed according to the type of dairy product and body mass status.

Calcium in food seems to play an important role in this relationship. Zemel et al. [115] found an unexpected side effect in a study in which they investigated the effect of calcium on blood pressure. Not only was there a significant decrease in blood pressure after increased calcium intake from 400 to $1000 \mathrm{mg}$, but there was also a significant reduction in body fat by $4.9 \mathrm{~kg}$. These findings were confirmed in some further studies, but not in all $[95,103$, 113]. Regardless of exercise group assignment, calcium (adjusted for energy intake) had a negative and vitamin $\mathrm{A}$ intake a positive correlation with the changes in total body weight and body fat over two years in young women aged 18 to 31 . Thus, subjects with high calcium intake, corrected for total energy intake, and low vitamin A intake gained less weight and body fat over two years in this randomized exercise intervention trial [49]. 
The exact mechanism is still unclear, but it may be partly due to the formation of calcium and fatty acid complexes in the gut, preventing their absorption. Dietary calcium suppresses calcitriol, stimulates lipolysis and decreases adipocyte lipid accumulation [114]. Furthermore, milk and cheese are high in protein, which bestows them with a relatively high satiety value, helpful in a calorie-restricted diet $[32,95]$. Additionally, total daily energy intake is significantly higher when high-carbohydrate, fat and protein foods are ingested as liquids rather than as solids [59]. Nevertheless, other bioactive compounds in dairy products such as CLA may also have an influence on weight control and body composition $[15,46,107,108]$. However, the results in human studies are still not consistent $[45,61,66,91,100]$.

Accumulation of abdominal body fat is associated with an even greater health risk than the same amount of fat deposited around the hips $[5,8,44]$. In an animal experiment the effects of Goudatype cheese on biological markers of the metabolic syndrome were examined. The study revealed a significantly lower weight of mesenteric adipose tissue in cheese-fed rats on a $20 \%$ fat diet compared with rats fed a similar high-fat diet containing casein and butterfat. The amount of cholesterol in very low-density lipoprotein and the serum levels of low-density lipoprotein were lower in rats receiving the cheese diet. Thus, cheese consumption might have a beneficial suppressive effect on abdominal adipose accumulation, which is one of the known risk factors for the development of metabolic syndrome [35].

\subsection{Anti-hypertensive property}

In western countries hypertension is a major risk factor for both coronary heart disease and stroke. In several studies dairy products have shown a beneficial effect on blood pressure, especially in mildly hypertensive subjects. Two main components seem to be relevant in this situation: calcium and bioactive peptides.

The inverse relationship between calcium intake and blood pressure was first suggested by several epidemiological surveys in the early 1980 s, because populations with low calcium intake often had an increased prevalence of hypertension. Subsequent laboratory and clinical investigations provided further evidence for the association between calcium and blood pressure, but the results of these studies were often inconsistent $[83,92,102]$.

A meta-analysis of 28 studies accomplished by Allender et al. [1] showed a significant decrease in systolic blood pressure with calcium supplementation, both for hypertensive individuals and for the overall sample. However, according to these authors, the effect is too small to designate the use of calcium supplementation for preventing or treating hypertension. The same conclusion was drawn [10] in a similar analysis of 33 studies between 1966 and 1994. On the other hand, a diet with (low-fat) dairy products seems to reduce the incidence of hypertension with a significant effect on primary prevention of cardiovascular diseases [53]. Besides calcium, potassium and magnesium also seem to have a beneficial effect on blood pressure. This is another reason why dairy products, as a good source of all three minerals, are recommended to reach the recommended daily allowance (RDA) of calcium $[33,50]$.

The randomized, controlled, clinical study "Dietary Approaches to Stop Hypertension Study" ("DASH"-Study) carried out between 1994 and 1996 demonstrated a dramatic blood pressure-lowering effect of a diet rich in dairy products, fruits and vegetables [2, 79]. Miller et al. [56] summarized in their survey that the consumption of dairy products, at the currently recommended level by expert panels, optimizes blood pressure 
regulation in humans. Furthermore, failure to ingest adequate amounts of dairy products increases the risk of hypertensive heart disease. They draw their conclusions on the meta-analysis of observational studies as well as on randomized controlled trials, metabolic investigations, experimental studies of laboratory models of hypertension and basic research to identify biologically relevant mechanisms of how dairy product intake might optimize arterial pressure control. Recently published studies confirm the above-mentioned findings and show a beneficial effect of various dairy products on blood pressure [95]. Some results suggest an additional inverse association of dairy products and prevalent hypertension independent of dietary calcium $[17,78,95]$.

Cheese is a rich source of bioactive peptides. Among these peptides, one of the most interesting and investigated biological functions is the angiotensin-converting enzyme (ACE)-inhibitory effect. ACE is a key enzyme in the regulation of blood pressure, because it enables the conversion of angiotensin I into the highly potent vasoconstrictor angiotensin II and inactivates the depressing action of bradykinin. By inhibiting the effect of ACE, these peptides have a positive influence on hypertension, although their effect is less pronounced than what has been observed with drugs based on the same principle. ACE-inhibiting peptides have been found in several food proteins [48]. Meisel et al. [54] list over 200 amino acid sequences derived from milk, animal (nonmilk), plant and miscellaneous protein sources with an ACE-inhibitory effect. The chain length varies from 2 to 20 amino acids and the potency of these peptides is also extremely different. In cheese, these peptides are produced during secondary proteolysis through the action of proteinases and peptidases. Several studies have shown ACE-inhibitory activity in various cheese varieties with different bioac- tive peptides being responsible for that effect (Tab. III) [27, 80, 94, 97]. Among these different ACE-inhibiting peptides, the tripeptides valyl-prolyl-proline (VPP) and isoleucyl-prolyl-proline (IPP) belong to the most potent ACE-inhibiting peptide group. They are easily absorbed by the intestine and it has been shown that peptides containing a C-terminal Pro-Pro sequence are rather resistant to further degradation by digestive proteases and peptidases [21]. VPP and IPP are encrypted in the $\beta$-casein of milk. Proteinases from the lactic acid bacteria L. helveticus have the potential to release these two peptides in fermented milk. Various in vivo experiments showed a hypotensive effect in spontaneous hypertensive rats fed with sour milk fermented with special strains of L. helveticus $[51,63,67,93]$, as well as in humans [29, 57, 62, 84, 104].

The fact that $L$. helveticus is a common strain used in cheese-making, and that during ripening intense proteolysis takes place, led to the assumption that cheese may also show ACE-inhibiting activity due to the formation of VPP and IPP. However, the quantitative determination of these two peptides in cheese was a problem. This problem has now been solved by the development of a method based on liquid chromatography with subsequent triple mass spectrometry $\left(\mathrm{LC}-\mathrm{MS}^{3}\right)$. The application of this method to the analysis of 44 traditional cheese varieties (Swiss and non-Swiss cheeses) showed that the concentrations of VPP and IPP varied widely from $0-224 \mathrm{mg} \cdot \mathrm{kg}^{-1}$ and $0-95 \mathrm{mg} \cdot \mathrm{kg}^{-1}$, respectively. There was an increasing trend from low concentrations in soft cheese, average concentrations in semi-hard and hard cheeses and high concentrations in extra-hard cheeses [12]. A second study investigated the occurrence of the ACE-inhibiting tripeptides VPP and IPP in 11 cheese varieties of Swiss origin [11]. In individual samples, the total concentration of VPP and IPP 
Table III. ACE-inhibiting di-, tri-, tetra- and pentapeptides found in different cheeses.

\begin{tabular}{llcc}
\hline Peptide & Amino acids ${ }^{1}$ & Cheese variety & Literature \\
\hline Di- & QP, PP, FP, RI/RL & Spanish origin & {$[27]$} \\
Tri- & VPP, IPP & Swiss origin & {$[11,12]$} \\
& FPE, IPY, PFP, PQL, AWY, PSE, EEL/EEI, & Spanish origin & {$[25,27]$} \\
& RPK, MPI/MPL, REL, & & \\
& RPK & Cheese-like system of caprine milk & {$[90]$} \\
Tetra- & VRYL, HPIK, HQGL, NINE, ERYL, & Spanish origin & {$[26,27]$} \\
& ENLL, EVLN, VRGP, GVPK, VRGP, & & \\
& GVPK, EVVR, GPIH, PEVP & & {$[90]$} \\
& YQEP & & \\
Penta- & DKIHP, RPKHP, EIVPK, PQEVL, NENLL, & Spanish origin & \\
& NLLRF, VVVPP, TDVEK, PGPIH, PVEPF & & \\
\hline
\end{tabular}

${ }^{1}$ One-letter abbreviation of amino acids.

varied from 1.6 to $424.5 \mathrm{mg} \cdot \mathrm{kg}^{-1}$, indicating that some cheese varieties contain VPP and IPP concentrations similar to fermented milk products with blood pressure-lowering capacities of commercial products sold nowadays. The results also indicate that different factors such as milk pretreatment and cultures, as well as scalding and ripening times, contribute to the concentration of VPP and IPP in cheese. Further studies are needed to determine the main influencing factor(s) to develop a cheese with constantly high concentrations of the two described bioactive peptides. In order to demonstrate the hypotensive effect of cheese containing significant amounts of VPP and IPP, it will be necessary to carry out in vivo studies in spontaneous hypertensive rats and/or hypertensive patients similar to those carried out with fermented milk products.

\subsection{Beneficial effect on bone health}

The role of calcium in bone health is well documented and recognized [31]. As discussed above, cheese can provide a significant amount of calcium, especially in the diet of lactose-intolerant individuals.
Female adolescents, limiting the intake of dairy products because of self-perceived milk intolerance, have a significantly lower intake of calcium as well as a significantly lower spinal bone mineral content than female adolescents without perceived milk intolerance [52]. Kato et al. [43] could even show, in their experiments with rats, that milk calcium taken with cheese is even better absorbed than milk calcium taken without cheese. And as a consequence, the bone mineral density of the rats fed milk calcium with cheese was significantly higher than in the control group. Cheng et al. [14] supported the results of Kato et al. [43] in their study with 10to 12-year-old children. Calcium supplementation with cheese resulted in a higher change in cortical thickness of the tibia than the placebo, or treatment with calcium supplementation in the form of pills with or without vitamin D. Cheese was significantly better than placebo treatment with respect to whole-body bone mineral density.

Besides calcium other cheese compounds such as magnesium and vitamin $\mathrm{D}$ also play an important role in building up bone mineral density and reducing 
bone loss. However, phosphorus has a hypocalciuric effect, so that the consumption of cheese with its remarkable amount of phosphorus might have a negative effect on bone mineral density. Bizik et al. [7] could not confirm this hypothesis with their study, in which they doubled the consumption of phosphorus in healthy young men by the addition of cheese and milk. High phosphorus intake does not promote bone resorption if the calcium to phosphorus ratio is $<1: 1.5$, which is the case in cheese.

Besides calcium other cheese compounds such as magnesium and vitamin $\mathrm{D}$ and even some bioactive peptides also play an important role in building up bone mineral density and reducing bone loss. Recent clinical studies suggest that several anti-hypertensive drugs, especially ACE-inhibitors, reduced bone fractures, because angiotensin II, a potent vasoconstrictor, also affects bone by activating osteoblasts [85]. VPP, a small peptide, formed during fermentation of milk with L. helveticus, has been shown to possess ACE-inhibitory activity (see above).

In an animal study with ovariectomized rats, the group fed with $L$. helveticusfermented milk significantly prevented bone loss by decreasing bone turnover and increasing bone mineral density [65]. VPP in water could not prevent bone loss and the authors concluded that this might be due to the poor bioavailability of the bioactive peptide in water. It is not clear whether the preventive effect of the fermented milk is due to VPP. Because VPP is known to have a lowering effect on blood pressure, these results show an interesting connection to a study by Metz et al. [55]. They investigated the relationship between blood pressure, dietary calcium and bone mass. The findings show that blood pressure was negatively related to bone mineral density and bone mineral content independent of age, BMI and calcium intake. The observational nature of the study precluded causal- ity, which is supported by experimental data associating hypertension with calcium metabolism. Therefore, it is hypothesized that hypertension may be related to the risk of osteoporosis. At any rate, in females with primary hypertension, bone strength, although fitting for chronological age and body height, was lower than expected for body weight [70].

\subsection{Anti-carcinogenic effects}

The World Cancer Research Fund and the American Institute for Cancer Research [112] have recently examined the literature on food and cancer. Cheese consumption was related to colorectal and prostate cancer. Eleven cohort studies and 25 case-control studies exist, showing a correlation between colorectal cancer and cheese. Due to inconsistency of the results, they declared that the evidence for cheese consumption as a cause for colorectal cancer was limited. Prostate cancer was discussed because of numerous associations between dairy product and calcium (dietary and supplemental) consumption in epidemiological studies. The report mentioned above evaluated 9 cohort studies, 12 case-control studies and 2 ecological studies for the relation between dietary calcium and prostate cancer. A dose-response relationship was apparent from cohort but not case-control data. However, a coherence of prostate cancer and calcium only correlates with diets very high in calcium ( $1.5 \mathrm{~g} \cdot \mathrm{d}^{-1}$ or more). Diets high in calcium are a probable cause of prostate cancer. According to the panel there is, however, limited evidence that high consumption of milk and dairy products is a cause of prostate cancer.

These findings could be explained by the presence of anti-carcinogenic compounds such as CLA and sphingolipids in cheese. Almost 20 years ago an initial study suggested an anti-mutagenic 
activity of CLA. Since then considerable in vitro experiments and animal trials have been carried out concerning CLA inhibition of carcinogenesis. It is assumed that CLA is involved in various steps in all three stages of carcinogenesis, exerting its effect by modulation of cell proliferation and apoptosis, regulation of gene expression, influence on eicosanoid synthesis and metabolism, and anti-oxidative mechanisms [6]. Further studies will have to provide information on possible anti-carcinogenic effects in humans. Experiments have shown that the CLA concentration in blood can be enhanced by the consumption of CLA-rich cheese [36].

Another interesting group of lipids relating to the prevention of cancer are the sphingolipids. There are no human trials or epidemiological studies evaluating a protective effect on the development and progression of colon cancer. Based on the fact that sphingolipids reduce markers of colon cancer in animal trials and that their metabolites induce spontaneous cell death in human cancer cells, it is highly probable that sphingolipids also have anticarcinogenic properties in humans [106]. Besides soybeans $\left(189 \mathrm{mg} \cdot \mathrm{kg}^{-1}\right)$, the best sources of these lipids are milk, full cream, butter and cheese, containing 115, 490, 710 and $995 \mathrm{mg} \cdot \mathrm{kg}^{-1}$, respectively. They provide about one-third of the total intake in countries with high dairy product consumption, such as Switzerland. Because of their amphiphile character and their distribution in the milk fat globule membrane, quantitative determination in milk products is very difficult $[106,109]$.

\section{CONCLUSIONS}

Cheese has a long history in the human diet to which it contributes a substantial amount of important nutrients; in particular, proteins, bioactive peptides, amino acids, fat, fatty acids, vitamins and minerals. Research today is concentrated more and more on the influence of nutrition on human health. Calcium, which is present in large quantities in cheese, has been shown to have a positive effect on various disorders (hypertension, osteoporosis, obesity and dental caries). Besides calcium, other constituents with potentially positive effects on health are found, e.g. bioactive peptides, which also decrease hypertension. In humans, the possible anti-carcinogenic effects of specific lipids (CLA, sphingolipids) have not yet been investigated but animal studies suggest a certain potential. Cheese still has a negative image because of its fatty acid composition. However, research has uncovered ever more details, whereby these old convictions have started to waver. Further studies are needed both to confirm earlier results and clarify their mechanism as well as to discover further interesting cheese constituents and their effects. Besides all this scientific research, the inseparable tradition and enjoyment of cheese should not be forgotten. Cheese is more than the sum of its constituents.

\section{REFERENCES}

[1] Allender P.S., Cutler J.A., Follmann D., Cappuccio F.P., Pryer J., Elliott P., Dietary calcium and blood pressure: a metaanalysis of randomized clinical trials, Ann. Intern. Med. 124 (1996) 825-831.

[2] Appel L.J., Moore T.J., Obarzanek E., Vollmer W.M., Svetkey L.P., Sacks F.M., Bray G.A., Vogt T.M., Cutler J.A., Windhauser M.M., Lin P.H., Karanja N., A clinical trial of the effects of dietary patterns on blood pressure, N. Engl. J. Med. 336 (1997) 1117-1124.

[3] Ashley F.P., Coward P.Y., Jalil R.A., Wilson R.F., Relationship between calcium and inorganic phosphorus concentrations of both resting and stimulated saliva and dental plaque in children and young adults, Arch. Oral Biol. 36 (1991) 431-434.

[4] Bachmann H.P., Bütikofer U., Sieber R., Über das Vorkommen von bioaktiven 
Peptiden in Käse, Mitt. Lebensm. Hyg. 94 (2003) 136-154.

[5] Behn A., Ur E., The obesity epidemic and its cardiovascular consequences, Curr. Opin. Cardiol. 21 (2006) 353-360.

[6] Belury M.A., Inhibition of carcinogenesis by conjugated linoleic acid: Potential mechanisms of action, J. Nutr. 132 (2002) 2995-2998.

[7] Bizik B.K., Ding W., Cerklewski F.L., Evidence that bone resorption of young men is not increased by high dietary phosphorus obtained from milk and cheese, Nutr. Res. 16 (1996) 1143-1146.

[8] Boursier V., Metabolic syndrome, J. Mal. Vasc. 31 (2006) 190-201.

[9] Braun S.D., Nimmagudda R., Methods for treating or preventing diseases of the oral cavity, US Patent 6890900 (2005).

[10] Bucher H.C., Cook R.J., Guyatt G.H., Lang J.D., Cook D.J., Hatala R., Hunt D.L., Effects of dietary calcium supplementation on blood pressure: a meta-analysis of randomized controlled trials, J. Am. Med. Ass. 275 (1996) 1016-1022.

[11] Bütikofer U., Meyer J., Sieber R., Walther B., Wechsler D., Occurrence of the angiotensin-converting enzyme-inhibiting tripeptides Val-Pro-Pro and Ile-Pro-Pro in different cheese varieties of Swiss origin, J. Dairy Sci. 91 (2008) 29-38.

[12] Bütikofer U., Meyer J., Sieber R., Wechsler D., Quantification of the angiotensinconverting enzyme-inhibiting tripeptides Val-Pro-Pro and Ile-Pro-Pro in hard, semihard and soft cheeses, Int. Dairy J. 17 (2007) 968-975.

[13] Chardigny J.M., Destaillat F., MalpuechBrugère C., Moulin J., Bauman D.E., Lock A.L., Barbano D.M., Mensink R.P., Bezelgues J.B., Chaumont P., Combe N., Cristiani I., Joffre F., German J.B., Dionisi F., Boirie Y., Sébédio J.L., Do trans fatty acids from industrially produced sources and from natural sources have the same effect on cardiovascular disease risk factors in healthy subjects? Results of the trans Fatty Acids Collaboration (TRANSFACT) study, Am. J. Clin. Nutr. 87 (2008) 558-566.

[14] Cheng S., Lyytikainen A., Kroger H., Lamberg-Allardt C., Alen M., Koistinen A., Wang Q.J., Suuriniemi M., Suominen H., Mahonen A., Nicholson P.H.F., Ivaska K.K., Korpela R., Ohlsson C., Vaananen K.H., Tylavsky F., Effects of calcium, dairy product, and vitamin D supplementation on bone mass accrual and body composition in 10-12-y-old girls: a 2-y randomized trial, Am. J. Clin. Nutr. 82 (2005) 1115-1126.

[15] Colakoglu S., Colakoglu M., Taneli F., Cetinoz F., Turkmen M., Cumulative effects of conjugated linoleic acid and exercise on endurance development, body composition, serum leptin and insulin levels, J. Sports Med. Phys. Fitness 46 (2006) 570-577.

[16] Collomb M., Bütikofer U., Sieber R., Bosset J.O., Jeangros B., Conjugated linoleic acid and trans fatty acid composition of cows' milk fat produced in lowlands and highlands, J. Dairy Res. 68 (2001) 519523.

[17] Djoussé L., Pankow J.S., Hunt S.C., Heiss G., Province M.A., Kabagambe E.K., Ellison R.C., Influence of saturated fat and linolenic acid on the association between intake of dairy products and blood pressure, Hypertension 48 (2006) 335-341.

[18] Dreizen S.A.M.U., Dreizen J.G., Stone R.E., The effect of cow's milk on dental caries in the rat, J. Dent. Res. 40 (1961) 1025-1028.

[19] Edgar W.M., Bowen W.H., Amsbaugh S., Monell-Torrens E., Brunelle J., Effects of different eating patterns on dental caries in the rat, Caries Res. 16 (1982) 384-389.

[20] Eichholzer M., Camenzind E., Matzke A., Amadò R., Ballmer P.E., Beer M., Darioli R., Hasler K., Lüthy J., Moser U., Sieber R., Trabichet C., Fünfter Schweizerischer Ernährungsbericht, Bundesamt für Gesundheit, Bern, 2005.

[21] Foltz M., Meynen E.E., Bianco V., van Platerink C., Koning T.M.M.G., Kloek J., Angiotensin converting enzyme inhibitory peptides from a lactotripeptideenriched milk beverage are absorbed intact into the circulation, J. Nutr. 137 (2007) 953-958.

[22] Fox P.F., O'Connor T.P., McSweeney P.L.H., Guinee T.P., O’Brien N.M., Cheese: physical, biochemical, and nutritional aspects, Adv. Food Nutr. Res. 39 (1995) 163328.

[23] German J.B., Dillard C.J., Saturated fats: what dietary intake?, Am. J. Clin. Nutr. 80 (2004) 550-559.

[24] Glabska D., Sinska B., Remiszewski A., [Analysis of the dependence between milk and dairy products consumption, and dental caries observed in group of children and teenagers], Rocz. Panstw. Zakl. Hig. 58 (2007) 69-75.

[25] Gómez-Ruiz J.Á., Ramos M., Recio I., Angiotensin-converting enzyme-inhibitory 
peptides in Manchego cheeses manufactured with different starter cultures, Int. Dairy J. 12 (2002) 697-706.

[26] Gómez-Ruiz J.Á., Ramos M., Recio I., Identification and formation of angiotensinconverting enzyme-inhibitory peptides in Manchego cheese by high-performance liquid chromatography-tandem mass spectrometry, J. Chromatogr. A 1054 (2004) 269-277.

[27] Gómez-Ruiz J.Á., Taborda G., Amigo L., Recio I., Ramos M., Identification of ACEinhibitory peptides in different Spanish cheeses by tandem mass spectrometry, Eur. Food Res. Technol. 223 (2006) 595-601.

[28] Guggenheim B., Schmid R., Aeschlimann J.M., Berrocal R., Neeser J.R., Powdered milk micellar casein prevents oral colonization by Streptococcus sobrinus and dental caries in rats: A basis for the cariesprotective effect of dairy products, Caries Res. 33 (1999) 446-454.

[29] Hata Y., Yamamoto M., Ohni M., Nakajima K., Nakamura Y., Takano T., A placebocontrolled study of the effect of sour milk on blood pressure in hypertensive subjects, Am. J. Clin. Nutr. 64 (1996) 767-771.

[30] Hayes K.C., Pronczuk A., Lindsey S., Diersenschade D., Dietary saturated fatty acids $(12: 0,14: 0,16: 0)$ differ in their impact on plasma cholesterol and lipoproteins in nonhuman primates, Am. J. Clin. Nutr. 53 (1991) 491-498.

[31] Heaney R.P., Calcium, dairy products and osteoporosis, J. Am. Coll. Nutr. 19 (2000) 83S-99S.

[32] Heaney R.P., Calcium intake and disease prevention, Arq. Bras. Endocrinol. Metabol. 50 (2006) 685-693.

[33] Henry H.J., McCarron D.A., Morris C.D., Parrott-Garcia M., Increasing calcium intake lowers blood pressure: the literature reviewed, J. Am. Diet. Assoc. 85 (1985) 182185.

[34] Heyman M.B., for the Committee on nutrition, Lactose intolerance in infants, children, and adolescents, Pediatrics 118 (2006) 1279-1286.

[35] Higurashi S., Kunieda Y., Matsuyama H., Kawakami H., Effect of cheese consumption on the accumulation of abdominal adipose and decrease in serum adiponectin levels in rats fed a calorie dense diet, Int. Dairy J. 17 (2007) 1224-1231.

[36] Huang T.T., McCrory M.A., Dairy intake, obesity, and metabolic health in children and adolescents: knowledge and gaps, Nutr. Rev. 63 (2005) 71-80.

[37] IDF, The world dairy situation 2006, 409 (2006) 1-92.

[38] IDF, The world dairy situation 2007, 423 (2007) 1-97.

[39] Jakobsen M.U., Overvad K., Dyerberg J., Heitmann B.L., Intake of ruminant trans fatty acids and risk of coronary heart disease, Int. J. Epidemiol. 37 (2008) 173-182.

[40] Jenkins G.N., Ferguson D.B., Milk and dental caries, Brit. Dent. J. 120 (1966) 472477.

[41] Jensen M.E., Donly K., Wefel J.S., Assessment of the effect of selected snack foods on the remineralization/ demineralization of enamel and dentin, J. Contemp. Dent. Pract. 1 (2000) 1-17.

[42] Jensen M.E., Harlander S.K., Schachtele C.F., Evaluation of the acidogenic and antacid properties of cheeses by telemetric monitoring of human dental plaque $\mathrm{pH}$, in: Hefferren J.J., Osborn J.C., Koehler H.M. (Eds.), Foods, Nutrition and Dental Health, American Dental Association, Chicago, USA, 1984, pp. 31-47.

[43] Kato K., Takada Y., Matsuyama H., Kawasaki Y., Aoe S., Yano H., Toba Y., Milk calcium taken with cheese increases bone mineral density and bone strength in growing rats, Biosci. Biotechnol. Biochem. 66 (2002) 2342-2346.

[44] Lam G.A., Mobarhan S., Central obesity and elevated liver enzymes, Nutr. Rev. 62 (2004) 394-399.

[45] Larsen T.M., Toubro S., Gudmundsen O., Astrup A., Conjugated linoleic acid supplementation for $1 \mathrm{y}$ does not prevent weight or body fat regain, Am. J. Clin. Nutr. 83 (2006) 606-612.

[46] Laso N., Brugué E., Vidal J., Ros E., Arnaiz J.A., Carné X., Vidal S., Mas S., Deulofeu R., Lafuente A., Effects of milk supplementation with conjugated linoleic acid (isomers cis-9, trans-11 and trans-10, cis-12) on body composition and metabolic syndrome components, Brit. J. Nutr. 98 (2007) 860-867.

[47] Law B.A., Flavour development in cheeses, in: Davies F.L., Law B.A. (Eds.), Advances in the microbiology and biochemistry of cheese and fermented milk, Elsevier Appl. Sci. Publ., London, UK, 1984, pp. 187-208.

[48] Li G.H., Le G.W., Shi Y.H., Shrestha S., Angiotensin I-converting enzyme inhibitory peptides derived from food 
proteins and their physiological and pharmacological effects, Nutr. Res. 24 (2004) 469-486.

[49] Lin Y.C., Lyle R.M., McCabe L.D., McCabe G.P., Weaver C.M., Teegarden D., Dairy calcium is related to changes in body composition during a two-year exercise intervention in young women, J. Am. Coll. Nutr. 19 (2000) 754-760.

[50] Massey L.K., Dairy food consumption, blood pressure and stroke, J. Nutr. 131 (2001) 1875-1878.

[51] Masuda O., Nakamura Y., Takano T., Antihypertensive peptides are present in aorta after oral administration of sour milk containing these peptides to spontaneously hypertensive rats, J. Nutr. 126 (1996) 30633068.

[52] Matlik L., Savaiano D., McCabe G., VanLoan M., Blue C.L., Boushey C.J., Perceived milk intolerance is related to bone mineral content in 10- to 13-year-old female adolescents, Pediatrics 120 (2007) e669-e677.

[53] McCarron D.A., Reusser M.E., Hypertensive cardiovascular disease: risk reduction by dietary calcium and dairy foods, Sci. Alim. 22 (2002) 415-421.

[54] Meisel H., Walsh D.J., Murray B., FitzGerald R.J., ACE inhibiting peptides, in: Mine Y., Shahidi F. (Eds.), Nutraceutical proteins and peptides in health and disease, CRC Press, Boca Raton, USA, 2006, pp. 269-315.

[55] Metz J.A., Morris C.D., Roberts L.A., McClung M.R., McCarron D.A., Blood pressure and calcium intake are related to bone density in adult males, Brit. J. Nutr. 81 (1999) 383-388.

[56] Miller G.D., DiRienzo D.D., Reusser M.E., McCarron D.A., Benefits of dairy product consumption on blood pressure in humans: a summary of the biomedical literature, J. Am. Coll. Nutr. 19 (2000) 147S-164S.

[57] Mizushima S., Ohshige K., Watanabe J., Kimura M., Kadowaki T., Nakamura Y., Tochikubo O., Ueshima H., Randomized controlled trial of sour milk on blood pressure in borderline hypertensive men, Am. J. Hypertens. 17 (2004) 701-706.

[58] Molimard P., Spinnler H.E., Review: compounds involved in the flavor of surface mold-ripened cheeses: origins and properties, J. Dairy Sci. 79 (1996) 169-184.

[59] Mourao D.M., Bressan J., Campbell W.W., Mattes R.D., Effects of food form on appetite and energy intake in lean and obese young adults, Int. J. Obes. 31 (2007) 16881695.

[60] Moynihan P.J., Ferrier S., Jenkins G.N., The cariostatic potential of cheese: cooked cheese-containing meals increase plaque calcium concentration, Brit. Dent. J. 187 (1999) 664-667.

[61] Nagpal R., Yadav H., Puniya A.K., Singh K., Jain S., Marotta F., Conjugated linoleic acid: sources, synthesis and potential health benefits - an overview, Curr. Topics Nutraceut. Res. 5 (2007) 55-65.

[62] Nakamura Y., Kajimoto O., Kaneko K., Aihara K., Mizutani J., Ikeda N., Nishimura A., Kajimoto Y., Effects of the liquid yogurts containing "lactotripeptide (VPP, IPP)" on high-normal blood pressure, J. Nutr. Food 7 (2004) 123-137.

[63] Nakamura Y., Yamamoto N., Sakai K., Takano T., Antihypertensive effect of sour milk and peptides isolated from it that are inhibitors to angiotensin I-converting enzyme, J. Dairy Sci. 78 (1995) 1253-1257.

[64] Nammi S., Koka S., Chinnala K.M., Boini K.M., Obesity: an overview on its current perspectives and treatment options, Nutr. J. 3 (2004) 3-10.

[65] Narva M., Rissanen J., Halleen J., Vapaatalo H., Väänänen K., Korpela R., Effects of bioactive peptide, Valyl-ProlylProline (VPP), and Lactobacillus helveticus fermented milk containing VPP on bone loss in ovariectomized rats, Ann. Nutr. Metab. 51 (2007) 65-74.

[66] Ouignard-Boulange A., Clouet P., Schmitt B., Effects of dietary conjugated linoleic acids in the control of adiposity and obesity-related disorders, Eur. J. Lipid Sci. Technol. 109 (2007) 935-944.

[67] Pan D., Luo Y.K., Tanokura M., Antihypertensive peptides from skimmed milk hydrolysate digested by cell-free extract of Lactobacillus helveticus JCM1004, Food Chem. 91 (2005) 123-129.

[68] Pariza M.W., Perspective on the safety and effectiveness of conjugated linoleic acid, Am. J. Clin. Nutr. 79 (2004) 1132S-1136S.

[69] Pi-Sunyer F.X., Health implications of obesity, Am. J. Clin. Nutr. 53 (1991) 1595S$1603 \mathrm{~S}$.

[70] Pludowski P., Litwin M., Sladowska J., Antoniewicz J., Niemirska A., Wierzbicka A., Lorenc R.S., Bone mass and body composition in children and adolescents with primary hypertension: preliminary data, Hypertension 51 (2008) 77-83. 
[71] Reynolds E.C., Johnson I.H., Effect of milk on caries incidence and bacterial composition of dental plaque in the rat, Arch. Oral Biol. 26 (1981) 445-451.

[72] Rioux V., Catheline D., Bouriel M., Legrand P., Dietary myristic acid at physiologically relevant levels increases the tissue content of C20:5 n-3 and C20:3 n-6 in the rat, Reprod. Nutr. Dev. 45 (2005) 599-612.

[73] Rioux V., Daval S., Guillou H., Jan S., Legrand P., Although it is rapidly metabolized in cultured rat hepatocytes, lauric acid is used for protein acylation, Reprod. Nutr. Dev. 43 (2003) 419-430.

[74] Rioux V., Legrand P., Saturated fatty acids: simple molecular structures with complex cellular functions, Curr. Opin. Clin. Nutr. Metab. Care 10 (2007) 752-758.

[75] Rosell M., Hakansson N.N., Wolk A., Association between dairy food consumption and weight change over $9 \mathrm{y}$ in 19352 perimenopausal women, Am. J. Clin. Nutr. 84 (2006) 1481-1488.

[76] Roth J., Qiang X., Marban S.L., Redelt H., Lowell B.C., The obesity pandemic: where have we been and where are we going?, Obes. Res. 12 (2004) 88S-101S.

[77] Rugg-Gunn A.J., Edgar W.M., Geddes D.A.M., Jenkins G.N., The effect of different meal patterns upon plaque $\mathrm{pH}$ in human subjects, Br. Dent. J. 139 (1975) 351-356.

[78] Ruidavets J.B., Bongard V., Simon C., Dallongeville J., Ducimetiere P., Arveiler D., Amouyel P., Bingham A., Ferrieres J., Independent contribution of dairy products and calcium intake to blood pressure variations at a population level, J. Hypertens. 24 (2006) 671-681.

[79] Sacks F.M., Svetkey L.P., Vollmer W.M., Appel L.J., Bray G.A., Harsha D., Obarzanek E., Conlin P.R., Miller E.R., Simons-Morton D.G., Karanja N., Lin P.H., Effects on blood pressure of reduced dietary sodium and the dietary approaches to stop hypertension (DASH) diet, N. Engl. J. Med. 344 (2001) 3-10.

[80] Saito T., Nakamura T., Kitazawa H., Kawai Y., Itoh T., Isolation and structural analysis of antihypertensive peptides that exist naturally in Gouda cheese, J. Dairy Sci. 83 (2000) 1434-1440.

[81] Salter A.M., Mangiapane E.H., Bennett A.J., Bruce J.S., Billett M.A., Anderton K.L., Marenah C.B., Lawson N., White D.A., The effect of different dietary fatty acids on lipoprotein metabolism: concentration-dependent effects of diets enriched in oleic, myristic, palmitic and stearic acids, Brit. J. Nutr. 79 (1998) 195202.

[82] Schmid A., Schneider H., Golay A., Keller U., Economic burden of obesity and its comorbidities in Switzerland, Soz. Präventivmed. 50 (2005) 87-94.

[83] Schramm M.M., Cauley J.A., Sandler R.B., Slemenda C.W., Lack of an association between calcium intake and blood pressure in postmenopausal women, Am. J. Clin. Nutr. 44 (1986) 505-511.

[84] Seppo L., Jauhiainen T., Poussa T., Korpela R., A fermented milk high in bioactive peptides has a blood pressure-lowering effect in hypertensive subjects, Am. J. Clin. Nutr. 77 (2003) 326-330.

[85] Shimizu H., Nakagami H., Osako M.K., Hanayama R., Kunugiza Y., Kizawa T., Tomita T., Yoshikawa H., Ogihara T., Morishita R., Angiotensin II accelerates osteoporosis by activating osteoclasts, FASEB J. 22 (2008) 2465-2475.

[86] Sieber R., Zusammensetzung von Milch und Milchprodukten schweizerischer Herkunft, FAM-Information (2001) 1-23, available at http://www.db-alp.admin. ch/de/publikationen/docs/pub_SieberR 2001_15231.pdf.

[87] Sieber R., Käse - ein wertvolles Lebensmittel in der menschlichen Ernährung, Mitt. Lebensm. Hyg. 96 (2005) 141-170.

[88] Sieber R., Badertscher R., Fuchs D., Nick B., Beitrag zur Kenntnis der Zusammensetzung schweizerischer konsumreifer Weich- und Halbhartkäse, Mitt. Geb. Lebensm.-Unters. -Hyg. 85 (1994) 366-381.

[89] Sieber R., Stransky M., de Vrese M., Laktoseintoleranz und Verzehr von Milch und Milchprodukten, Z. Ernährungswiss. 36 (1997) 375-393.

[90] Silva S.V., Pihlanto A., Malcata F.X., Bioactive peptides in ovine and caprine cheeselike systems prepared with proteases from Cynara cardunculus, J. Dairy Sci. 89 (2006) 3336-3344.

[91] Silveira M.B., Carraro R., Monereo S., Tebar J., Conjugated linoleic acid (CLA) and obesity, Public Health Nutr. 10 (2007) 1181-1186.

[92] Simon J.A., Browner W.S., Tao J.L., Hulley S.B., Calcium intake and blood pressure in elderly women, Am. J. Epidemiol. 136 (1992) 1241-1247. 
[93] Sipola M., Finckenberg P., Korpela R., Vapaatalo H., Nurminen M.L., Effect of long-term intake of milk products on blood pressure in hypertensive rats, J. Dairy Res. 69 (2002) 103-111.

[94] Smacchi E., Gobbetti M., Peptides from several Italian cheeses inhibitory to proteolytic enzymes of lactic acid bacteria, Pseudomonas fluorescens ATCC 948 and to the angiotensin I-converting enzyme, Enzyme Microb. Technol. 22 (1998) 687694.

[95] Snijder M.B., van der Heijden A., van Dam R.M., Stehouwer C.D.A., Hiddink G.J., Nijpels G., Heine R.J., Bouter L.M., Dekker J.M., Is higher dairy consumption associated with lower body weight and fewer metabolic disturbances? The Hoorn Study, Am. J. Clin. Nutr. 85 (2007) 989995.

[96] Steffen C., Enzymatische Bestimmungsmethoden zur Erfassung der Gärungsvorgänge in der milchwirtschaftlichen Technologie, Lebensm.-Wiss. Technol. 8 (1975) 1-6.

[97] Stepaniak L., Jedrychowski L., Wroblewska B., Sørhaug T., Immunoreactivity and inhibition of angiotensin-I converting enzyme and lactococcal oligopeptidase by peptides from cheese, Ital. J. Food Sci. 13 (2001) 373-381.

[98] Subcommittee on the 10th Edition of the Recommended Dietary Allowances, Food and Nutrition Board, National Research Council, Recommended Dietary Allowances, National Academic Press, 1989.

[99] Temme E.H.M., Mensink R.P., Hornstra G., Comparison of the effects of diets enriched in lauric, palmitic, or oleic acids on serum lipids and lipoproteins in healthy women and men, Am. J. Clin. Nutr. 63 (1996) 897903.

[100] Terpstra A.H., Effect of conjugated linoleic acid on body composition and plasma lipids in humans: an overview of the literature, Am. J. Clin. Nutr. 79 (2004) 352-361.

[101] Tomé D., Bos C., Mariotti F., Gaudichon C., Protein quality and $\mathrm{FAO} / \mathrm{WHO}$ recommendations, Sci. Alim. 22 (2002) 393-405.

[102] Trevisan M., Krogh V., Farinaro E., Panico S., Mancini M., Calcium-rich foods and blood pressure: findings from the Italian National Research Council Study (the Nine Communities Study), Am. J. Epidemiol. 127 (1988) 1155-1163.

[103] Trowman R., Dumville J.C., Hahn S., Torgerson D.J., A systematic review of the effects of calcium supplementation on body weight, Brit. J. Nutr. 95 (2006) 1033-1038.

[104] Tuomilehto J., Lindström J., Hyyrynen J., Korpela R., Karhunen M.L., Mikkola L., Jauhiainen T., Seppo L., Nissinen A., Effect of ingesting sour milk fermented using Lactobacillus helveticus bacteria producing tripeptides on blood pressure in subjects with mild hypertension, J. Hum. Hypertens. 18 (2004) 795-802.

[105] Vedamuthu E.R., Washam C., Cheese, in: Reed G. (Ed.), Biotechnology, Verlag Chemie, Weinheim, Germany, 1983, pp. 231-313.

[106] Vesper H., Schmelz E.M., NikolovaKarakashian M.N., Dillehay D.L., Lynch D.V., Merrill A.H., Sphingolipids in food and the emerging importance of sphingolipids to nutrition, J. Nutr. 129 (1999) 1239-1250.

[107] Wang Y.W., Jones P.J.H., Dietary conjugated linoleic acid and body composition, Am. J. Clin. Nutr. 79 (2004) 1153S-1158S.

[108] Watras A.C., Buchholz A.C., Close R.N., Zhang Z., Schoeller D.A., The role of conjugated linoleic acid in reducing body fat and preventing holiday weight gain, Int. J. Obes. 31 (2007) 481-487.

[109] Wehrmüller K., Occurrence and biological properties of sphingolipids - a review, Curr. Nutr. Food Sci. 3 (2007) 161-173.

[110] Willett W.C., Trans fatty acids and cardiovascular disease - epidemiological data, Atherosclerosis, Suppl. 7 (2006) 5-8.

[111] Willett W.C., Stampfer M.J., Manson J.E., Colditz G.A., Speizer F.E., Rosner B.A., Sampson L.A., Hennekens C.H., Intake of trans fatty acids and risk of coronary heart disease among women, Lancet 341 (1993) 581-585.

[112] World Cancer Research Fund/American Institute for Cancer Research, Food, nutrition, physical activity, and the prevention of cancer: a global perspective, Washington DC, AICR (2007) 1-537.

[113] Zemel M.B., Calcium and dairy modulation of obesity risk, Obes. Res. 13 (2005) 192193.

[114] Zemel M.B., Miller S.L., Dietary calcium and dairy modulation of adiposity and obesity risk, Nutr. Rev. 62 (2004) 125-131.

[115] Zemel M.B., Shi H., Greer B., DiRienzo D., Zemel P.C., Regulation of adiposity by dietary calcium, FASEB J. 14 (2000) 11321138. 